\title{
Desain Self-Propelled Car Barge untuk Distribusi Mobil Baru Rute Cikarang Bekasi Laut (Cbl) - Tanjung Perak
}

\author{
Bintang Jiwa dan Hesty Anita Kurniawati \\ Jurusan Teknik Perkapalan, Fakultas Teknologi Kelautan, Institut Teknologi Sepuluh Nopember (ITS) \\ Jl. Arief Rahman Hakim, Surabaya 60111 Indonesia \\ e-mail: tita@na.its.ac.id
}

\begin{abstract}
Abstrak-Berbagai upaya telah dilakukan Pemerintah untuk dapat mengurangi kemacetan jalur Pantura. Mulai dari pemberian jalur alternatif, pelebaran jalan, hingga pembuatan jalan tol baru. Segala upaya tersebut tidak sebanding dengan jumlah kendaraan yang terus meningkat melewati jalur Pantura, khususnya kendaraan-kendaraan barang seperti truk dan kontainer. Hal ini tidak terlepas dari geliat perekonomian yang terus tumbuh. Kawasan industri otomotif di sekitar Cikarang dan Bekasi salah satu contohnya. Jumlah produksi mobil domestik dan permintaan yang terus meningkat ini membutuhkan sarana yang baik dan cepat dalam mendistribusikan mobil baru ke berbagai daerah. Dalam beberapa tahun ini, Jawa Timur merupakan provinsi dengan tingkat permintaan mobil yang cukup tinggi di Indonesia. Oleh karena itu, salah satu solusi yang ditawarkan untuk dapat mengurangi kemacetan di jalur darat adalah berupa pengalihan transportasi darat ke sungai atau laut. Berdasarkan solusi tersebut, maka dibutuhkan alat transportasi pengangkut barang, dalam hal ini mobil, yang dapat melewati sungai dan laut. SelfPropelled Car Barge diharapkan mampu menjadi inovasi yang cukup baik dalam mendistribusikan barang melalui rute Sungai Cikarang Bekasi Laut (CBL) menuju ke Pelabuhan Tanjung Perak. Untuk mendapatkan ukuran utama yang optimum digunakan metode optimation design approach dengan bantuan fitur solver pada program Microsoft Excel dengan menjadikan biaya pembangunan paling minimum sebagai fungsi objektif, serta adanya batasan-batasan dari persyaratan teknis dan regulasi yang ada. Dari proses optimisasi, didapatkan ukuran utama optimum Self-Propelled Car Barge adalah $\mathrm{L}=53.10 \mathrm{~m}$, $B=15.17 \mathrm{~m}, T_{F W}=3.09 \mathrm{~m}, T_{\mathrm{Sw}}=3.02 \mathrm{~m}$, dan $\mathrm{H}=4.66 \mathrm{~m}$, dengan estimasi biaya pembangunan sebesar $\$ 1.435 .270,56$ atau setara Rp.19.281.424.757,10.
\end{abstract}

Kata kunci: Tol Sungai, Distribusi Mobil Baru, Sungai CBL, Self-Prolled Barge

\section{PENDAHULUAN}

ETIAP tahun, angka pengguna jalur Pantura kian meningkat, terlebih pada high season seperti lebaran, termasuk distribusi logistik dan barang-barang kebutuhan lainnya yang masih menggunakan transportasi darat namun sayangnya tidak diimbangi dengan peningkatan kapasitas dan kualitas jalan raya. Tingginya anggaran perbaikan jalur Pantura nyatanya tidak menjamin arus transportasi yang lebih baik, hal tersebut dibuktikan dengan masih banyaknya kecelakaan lalu lintas akibat jalan rusak maupun antrian kemacetan yang mencapai belasan kilometer. Fakta di atas mengakibatkan perjalanan terhambat dan memakan waktu yang lebih lama, yang berimbas pada tingginya biaya operasional dan biaya eksternal transportasi darat.

Terkait dengan tujuan untuk mengembalikan identitas bangsa sebagai negara maritim, Presiden Joko Widodo sempat mencanangkan rencana pembangunan "Tol Sungai". Tol Sungai adalah mengembangkan sistem pengangkutan barang berbasis jalur sungai (inland access waterway) sepanjang 40 kilometer dari Kawasan Industri Cikarang, Jawa Barat melewati Sungai Cikarang Bekasi Laut (CBL) via Marunda, Jakarta Utara.

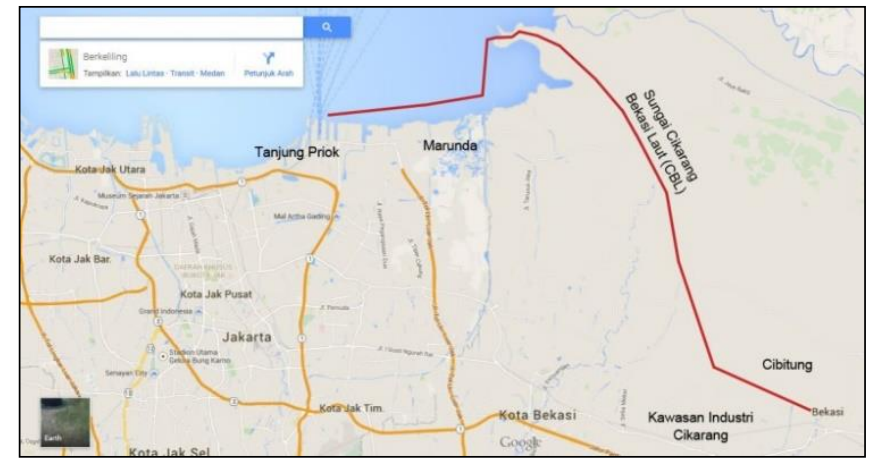

Gambar. 1. Jalur Tol Sungai CBL-Tanjung Priok (merah).

Karakteristik Sungai CBL yang memiliki dimensi yang panjang tanpa adanya simpangan yang tajam serta memiliki lebar sungai yang besar dijadikan acuan bagi pemerintah pusat untuk menunjuk Sungai CBL sebagai media pendistribusian Tol Sungai menggunakan kapal tongkang. Jenis kapal tongkang dipilih dengan tujuan agar mampu menampung muatan dalam jumlah yang besar, serta adanya batasan dari kondisi perairan yang menjadikan kapal memiliki batasan maksimum terhadap ukuran sarat dan lebar kapal. Namun hal ini tidak menjadi suatu persoalan bagi jenis kapal tongkang, mengingat tongkang memiliki dimensi lebar yang besar maka mampu untuk mengimbangi ukuran sarat yang lebih kecil, karena dengan displasemen yang sama dan lebar yang lebih besar, maka besar sarat yang dibutuhkan semakin kecil.

Jenis kapal Self-Propelled Car Barge dipilih sebagai jenis kapal yang digunakan dalam studi kali ini dikarenakan terdapat beberapa kelebihan umum antara SPB dengan tongkang, diantarnya, SPB telah dilengkapi oleh bangunan atas yang lebih sederhana sebagai tempat akomodasi para ABK (Anak Buah Kapal), sistem permesinan, sistem kemudi, 
sistem penggerak, serta perlengkapan dan peralatan. SPB biasa digunakan pada perairan yang tenang dan tidak memerlukan kecepatan yang tinggi. SPB sendiri kini sedang ramai dikembangkan di beberapa negara maju yang umumnya dijumpai di Eropa, Amerika, dan beberapa negara maju Asia seperti Tiongkok dan Jepang. SPB umumnya dipilih atas pertimbangan proses produksi yang mudah dilakukan serta biaya pembangunan yang dinilai lebih murah apabila dibandingkan dengan kapal konvensional.

\section{TINJAUAN PUSTAKA}

\section{A. Sungai Cikarang Bekasi Laut (CBL)}

Sungai CBL memiliki dimensi panjang keseluruhan sepanjang 28.205 meter dan kedalaman antara 4-7 meter dengan data teknis pada awal pembangunan yang didapatkan dari sebagai berikut:

Tabel 1.

Data Teknis Awal Pembangunan Sungai CBL [4]

\begin{tabular}{lcc}
\hline \multicolumn{1}{c}{ Nama Sungai/ Kali } & $\begin{array}{c}\text { Panjang } \\
\text { Sungai }(\mathrm{km})\end{array}$ & $\begin{array}{c}\text { Lebar Dasar } \\
\text { Sungai (m) }\end{array}$ \\
\hline Cikarang (Bendung CBL) - S. & 10,060 & 20,00 \\
Sadang & 2,000 & 30,00 \\
S. Sadang - S. Jambe & 5,825 & 40,00 \\
S. Jambe - S. Bekasi & 10,320 & 100,00 \\
S. Bekasi - Laut &
\end{tabular}

Pada tahun 2004 sudah pernah dilakukan normalisasi sungai pada ruas Sungai Bekasi - Laut sepanjang 12,00-kilometer yang dilaksanakan oleh PT. Adhi Karya. Namun pada ruas ini sudah terjadi pendangkalan dan penyempitan akibat sedimentasi yang cukup tinggi. Sehingga direncanakan untuk dilakukan normalisasi kembali dengan merencanakan kembali dimensi yang ideal guna mengurangi dampak banjir dan genangan di sekitar Sungai CBL. Adapun rencana desain untuk normalisasi Sungai CBL sebagai berikut:

Tabel 2.

Data Teknis Sungai CBL Setelah, Normalisasi pada Tahun 2004 [4]

\begin{tabular}{lcc}
\hline \hline \multicolumn{1}{c}{ Nama Sungai/ Kali } & $\begin{array}{c}\text { Panjang } \\
\text { Sungai }(\mathrm{km})\end{array}$ & $\begin{array}{c}\text { Lebar Dasar } \\
\text { Sungai (m) }\end{array}$ \\
\hline Cikarang (Bendung CBL) - S. & $0,20-6,60$ & - \\
Sadang & $9,10-10,50$ & 50,00 \\
S. Sadang - S. Jambe & $10,70-18,20$ & 60,00 \\
S. Jambe - S. Bekasi & $18,40-30,00$ & 80,00 \\
S. Bekasi - Laut &
\end{tabular}

\section{B. Self-propelled Container Barge}

Saat ini sedang marak dikembangkan inovasi mengenai tongkang berpenggerak sendiri atau self-propelled barge $(S P B)$. Terdapat beberapa perbedaan umum antara SPB dengan tongkang, diantarnya SPB telah dilengkapi oleh bangunan atas yang lebih sederhana sebagai tempat akomodasi para $\mathrm{ABK}$, permesinan, sistem kemudi, sistem penggerak, serta perlengkapan dan peralatan. SPB biasa digunakan pada perairan yang tenang dan tidak memerlukan kecepatan yang tinggi. [1][2] menjelaskan bahwa kapal tongkang yang beroperasi di sungai inland waterway dan perairan tenang pada umumnya memiliki kecepatan kapal antara 10-15 $\mathrm{km} / \mathrm{jam}$. SPB dapat disebut sebagai perpaduan antara kapal tongkang dan kapal konvensional, hal ini terlihat dari bentuk lambung bagian tengah yang hampir kotak menyerupai tongkang, akan tetapi pada bagian haluan dan buritan memiliki bentuk yang menyerupai kapal konvensional.

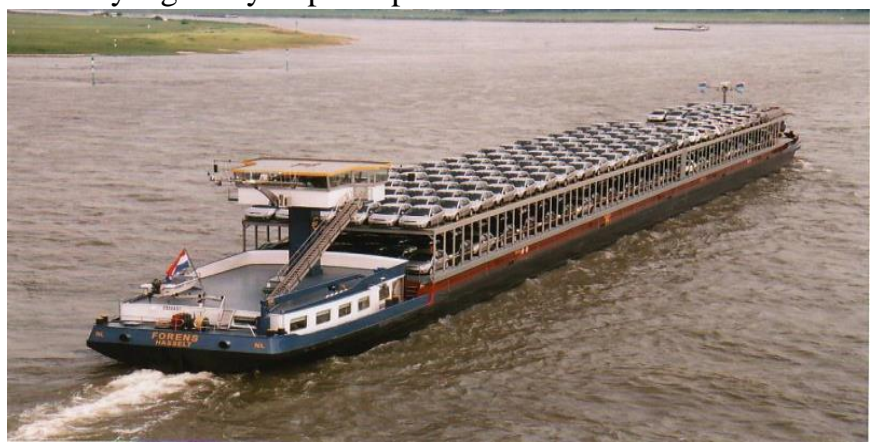

Gambar. 2. Self-Propelled Car Barge di sungai Rhine, Jerman [5]

Seperti sudah dijelaskan pada poin sebelumnya, pengertian dari Self-Propelled Car Barge merupakan jenis kapal tongkang yang memiliki sistem penggerak sendiri yang dirancang untuk mengangkut muatan mobil. Self-Propelled Car Barge saat ini digunakan sebagai moda transportasi pengangkut mobil di Eropa dan Jepang semenjak tahun 2000an. Sistem yang dikembangkan adalah pendistribusian mobil menggunakan Self-Propelled Car Barge melalui jalur sungai (inland waterway) dengan tujuan meningkatkan efisiensi biaya distribusi barang dan pengurangan beban jalan yang diakibatkan oleh truk.

\section{Supply \& Demmand Mobil Baru Domestik}

Kapasitas produksi industri otomotif di Indonesia terus bertambah. Hingga 2014 kapasitas produksi 1.928 .131 unit per tahun. Pada 2012, angka itu masih sekitar 630.000 unit per tahun. Produksi mobil oleh industri otomotif di Indonesia ditujukan untuk pasar domestik dan ekspor. Dalam road map Pemerintah RI, pada 2020 kemampuan produksi Indonesia ditargetkan mencapai 2,6 juta unit. Dari jumlah itu, 1,6 juta unit masuk pasar domestik.

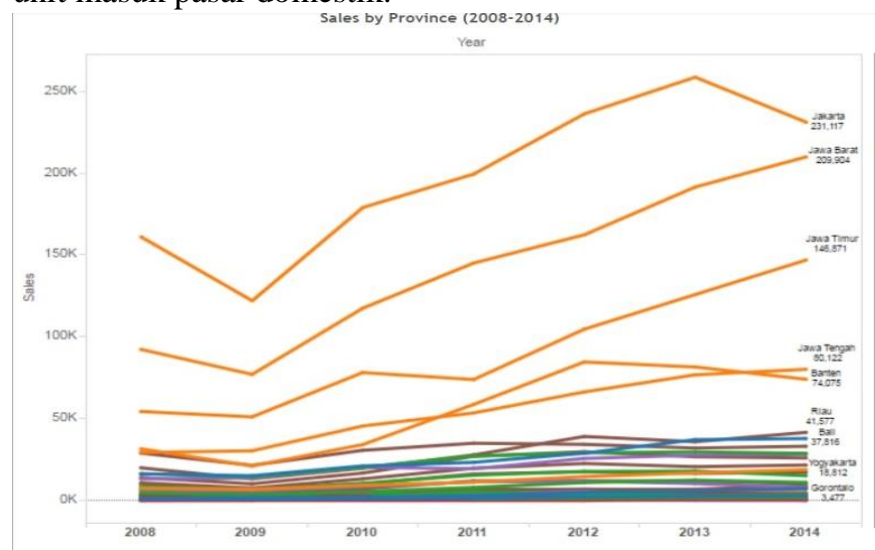

Gambar. 3. Penjualan Mobil di Indonesia 2010-2014

Dari data penjualan mobil domestik di atas dapat dilihat bahwa kawasan industri otomotif di Cikarang, Bekasi, dan Karawang membutuhkan sistem pendistribusian mobil baru ke Jawa Timur dalam skala yang lebih besar. dengan tujuan mengurangi beban jalur Pantura yang disebabkan volume kendaraan truk, serta guna menekan harga jual barang dengan cara meningkatkan efisiensi biaya distribusi. 


\section{Batasan Perairan Sungai}

Untuk kapal yang beroperasi di perairan sungai terdapat batasan perairan yang perlu diperhatikan mengingat sungai memiliki dimensi ukuran yang terbatas. Dimensi sungai sangatlah berpengaruh terhadap penentuan ukuran utama kapal, seperti lebar kapal dibatasi oleh lebar sungai, sarat kapal dibatasi oleh kedalaman sungai, panjang kapal dibatasi oleh lebar sungai apabila kapal tersebut perlu memutar balik, dan tinggi kapal di atas sarat dibatasi oleh air draft atau ketinggian maksimum apabila terdapat bangunan yang melintang di atas sungai seperti jembatan.

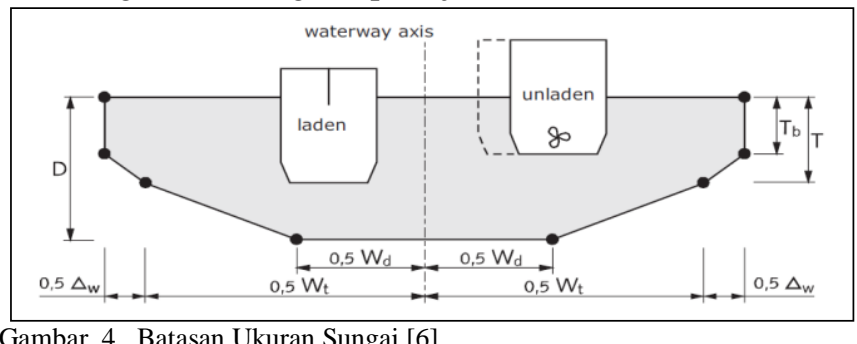

\section{E. The Geosim Procedure}

Pada umumnya untuk jenis kapal dengan jumlah keberadaan yang masih terbatas seperti kapal Self-Propelled Car Barge menggunakan metode Geosim Procedure dalam menentukan ukuran utama awal [3] menjelaskan Geosim Procedure merupakan metode penentuan ukuran utama yang digunakan ketika sebuah permintaan memiliki kesamaan geometris dengan kapal pembanding. Penentuan ukuran utama dilakukan berdasarkan koefisien perbandingan geometris ukuran utama (K). Dan data yang dibutuhkan untuk menggunakan metode ini adalah ukuran utama kapal seperti panjang kapal (L), lebar kapal (B), sarat kapal (T), dan tinggi kapal $(\mathrm{H})$, dengan $\mathrm{C}_{\mathrm{D}}$ (Coefficient Displacement) dan $\mathrm{C}_{\mathrm{B}}$ (Coefficient Block) yang dihasilkan memiliki nilai yang hampir serupa. Koefisien geometris (K) didapatkan dari persamaan Geosim di bawah ini:

$\mathrm{K}=\mathrm{L}_{2} / \mathrm{L}_{1}$

$\left(\mathrm{L}_{2} / \mathrm{L}_{1}\right)^{3}=\mathrm{W}_{2} / \mathrm{W}_{1}$

$\mathrm{L}_{2} / \mathrm{L}_{1}=\left(\mathrm{W}_{2} / \mathrm{W}_{1}\right)^{1 / 3}$

dimana:

$\mathrm{L}_{2} \quad=$ Panjang kapal yang dirancang

$\mathrm{L}_{1} \quad=$ Panjang kapal acuan

$\mathrm{W}_{2} \quad=$ DWT kapal yang dirancang

$\mathrm{W}_{1} \quad=$ DWT kapal acuan

\section{METODOLOGI PENELITIAN}

\section{A. Diagram Alir}

Metodologi dalam pengerjaan penelitian ini digambar dalam diagram alir (flow chart) pengerjaan sebagai berikut:

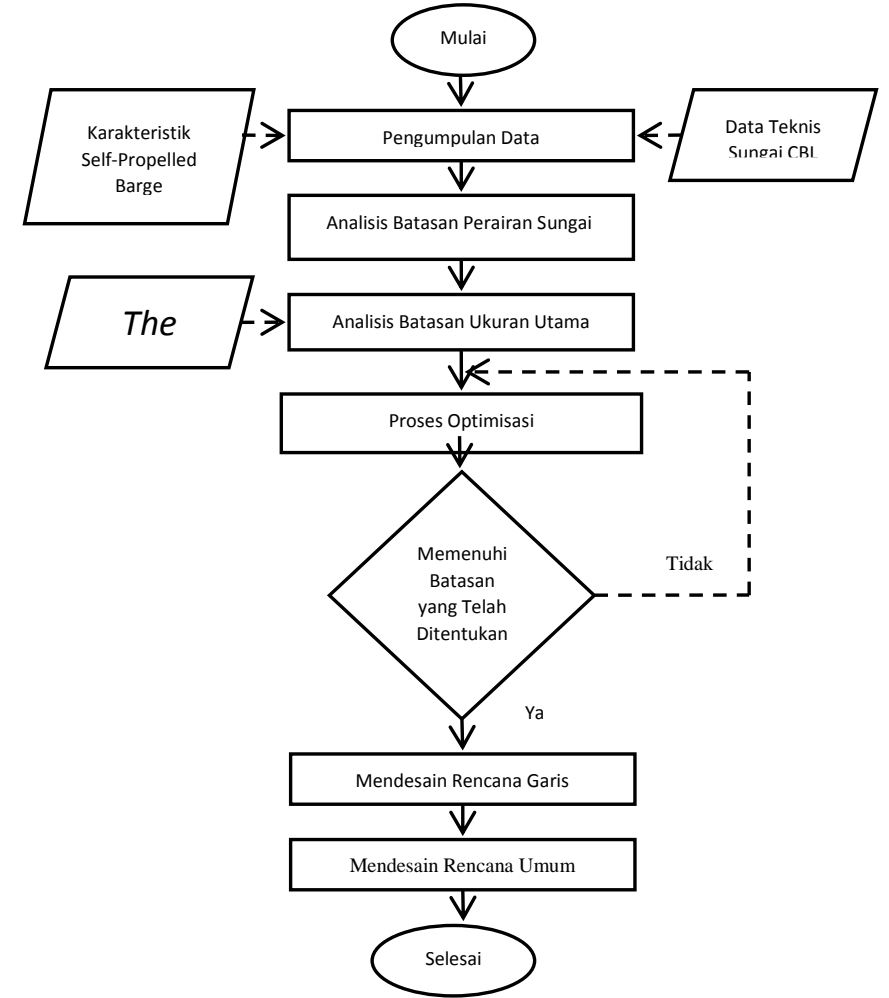

Gambar. 5. Diagram Alir Metodologi Penelitian

\section{B. Optimisasi Ukuran Utama}

Metode optimisasi adalah metode yang digunakan untuk mencari nilai optimum baik itu nilai maksimum ataupun minimum dari suatu fungsi matematis. Pada metode ini, fungsi tidak dapat berdiri sendiri tanpa adanya batasan-batasan, oleh karena itu sebelum dilakukannya perhitungan dengan metode tersebut, harus terlebih dahulu dilakukan penentuan objective function, variable, constrain, parameter, dan constanta.

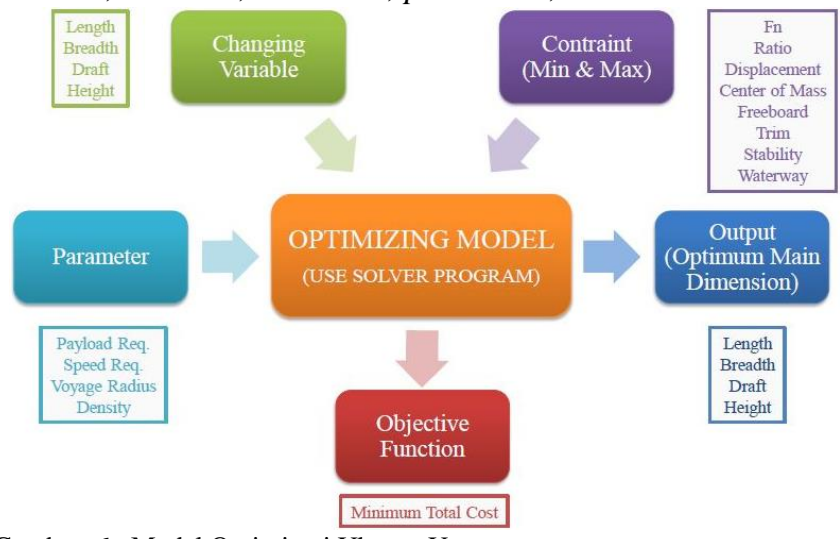

Gambar. 6. Model Optimisasi Ukuran Utama

\section{ANALISIS TEKNIS DAN EKONOMIS DESAIN}

\section{A. Design Statement}

Dari latar belakang masalah yang ada di atas, maka dapat disimpulkan data owner requirement dari Self-Propelled Car Barge adalah sebagai berikut:

1) Jenis kapal yang digunakan untuk program ini adalah Self-Propelled Barge (SPB), mengingat sebagian perairan yang dilalui adalah sungai yang memerlukan kemampuan 
olah gerak kapal yang cukup baik dikarenakan adanya batasan dari dimensi sungai itu sendiri.

2) Jenis muatan yang akan dimuat adalah mobil (car), untuk mengangkut barang dari Kawasan Industri Cikarang menuju Tanjung Perak.

3) Payload atau kapasitas muatan adalah 100 unit.

4) Kapal didesain dengan kecepatan 8 knot $(4,116 \mathrm{~m} /$ detik$)$, dengan estimasi waktu pelayaran normal yang dibutuhkan adalah 56,7 jam untuk pelayaran satu arah.

5) Radius pelayaran dari Bendung CBL menuju Pelabuhan Tanjung Perak sepanjang $40 \mathrm{~km}$, dengan $28,2 \mathrm{~km}$ melalui perairan sungai dan $811,12 \mathrm{~km}$ melalui perairan laut.

\section{B. Penentuan Ukuran Utama}

Metode penentuan ukuran utama yang digunakan dalam penelitian ini adalah dengan menggunakan metode optimisasi yang dibantu dengan penggunaan fitur Solver pada perangkat lunak Microsoft Excel. Parameter dari model optimisasi ditentukan sebagai berikut:

1) Objective Function

Pada proses optimisasi penentuan ukuran utama SelfPropelled Car Barge ini memiliki tujuan untuk mendapatkan ukuran utama kapal optimal yang mampu meningkatkan efisiensi dari biaya pembangunan, dengan mempertimbangkan aspek teknis yang ada. Pada model optimisasi ini digunakan objective function dengan nilai paling minimum dari biaya pembangunan.

2) Variabel (Changing Variable)

Digunakan untuk melakukan proses optimisasi ukuran utama Self-Propelled Car Barge antara lain adalah ukuran panjang, lebar, sarat, dan tinggi kapal.

3) Batasan (Constraint)

Batasan yang digunakan dalam proses optimasi meliputi batasan variabel ukuran utama, kondisi perairan sungai, froude number, rasio ukuran utama, berat dan titik berat, freeboard, dan stabilitas.

\section{Analisis Teknis Terhadap Hasil Optimisasi}

Setelah dilakukan proses optimisasi, maka didapat ukuran utama optimum Self-Propelled Car Barge yang telah memenuhi persyaratan teknis dan regulasi yang ada dengan estimasi biaya pembangunan paling efisien. Berikut merupakan analisa terhadap hasil optimisasi ukuran utama kapal pada dua kondisi perairan sungai dan laut:

Tabel 3.

Rekapitulasi Ukuran Utama Optimum

\begin{tabular}{crr}
\hline \hline & & \\
Main Dimension & Perairan Sungai & Perairan Laut \\
& & \\
\hline Length $\left(\mathrm{L}_{\mathrm{PP}}\right)$ & $53.097 \mathrm{~m}$ & $53.097 \mathrm{~m}$ \\
Length $\left(\mathrm{L}_{\mathrm{WL}}\right)$ & $55.221 \mathrm{~m}$ & $55.221 \mathrm{~m}$ \\
Breadth $(\mathrm{B})$ & $15.170 \mathrm{~m}$ & $15.170 \mathrm{~m}$ \\
Draft $(\mathrm{T})$ & $3.091 \mathrm{~m}$ & $3.016 \mathrm{~m}$ \\
Height $(\mathrm{H})$ & $4.663 \mathrm{~m}$ & $4.663 \mathrm{~m}$ \\
Vol. Disp. $(\overline{\mathrm{v}})$ & $2107.306 \mathrm{~m}^{3}$ & $2055.908 \mathrm{~m}^{3}$ \\
Disp. Ton $(\underline{\Lambda})$ & $2107.306 \mathrm{ton}$ & $2107.306 \mathrm{ton}$ \\
\hline \hline
\end{tabular}

Dari hasil ukuran utama yang didapatkan, maka dapat dilihat perbedaan ukuran utama untuk dua kondisi pelayaran, yang berdampak pada perbedaan hasil teknis berikutnya seperti perbedaan besar hambatan, kebutuhan daya mesin induk, berat, dan freeboard. Dari masing-masing ukuran utama diatas, didapatkan rasio ukuran utama dan koefisien kapal sebagai berikut:

Tabel 4.

Rekapitulasi Rasio Ukuran Utama dan Koefisien

\begin{tabular}{crr}
\hline \hline Rasio/Koefisien & Perairan Sungai & \multicolumn{1}{c}{ Perairan Laut } \\
\hline $\mathrm{L} / \mathrm{B}$ & 3.500 & 3.500 \\
$\mathrm{~B} / \mathrm{T}$ & 4.908 & 5.000 \\
$\mathrm{~L} / \mathrm{T}$ & 17.178 & 17.608 \\
$\mathrm{C}_{\mathrm{B}}$ & 0.814 & 0.814 \\
$\mathrm{C}_{\mathrm{M}}$ & 0.994 & 0.994 \\
$\mathrm{C}_{\mathrm{P}}$ & 0.818 & 0.818 \\
$\mathrm{C}_{\mathrm{WP}}$ & 0.884 & 0.884 \\
\hline
\end{tabular}

Setelah didapatkan rasio ukuran utama dan koefisien maka selanjutnya dilakukan perhitungan besar hambatan kapal dengan menggunakan metode Holtrop and Mannen dan kebutuhan daya mesin induk dengan dua rangkaian sistem penggerak (twin screw), maka didapatkan hasil:

Tabel 5.

Rekapitulasi Resistance and Powering

\begin{tabular}{crr}
\hline \hline Komponen & Perairan Sungai & \multicolumn{1}{c}{ Perairan Laut } \\
\hline $\mathrm{R}_{\mathrm{T}}$ & $34.189 \mathrm{kN}$ & $33.575 \mathrm{kN}$ \\
$\mathrm{P}_{\text {Req. }}$ & $210.894 \times 2 \mathrm{~kW}$ & $203.365 \times 2 \mathrm{~kW}$ \\
$\mathrm{P}_{\text {MainEngine }}$ & $279 \times 2 \mathrm{~kW}$ & $279 \times 2 \mathrm{~kW}$ \\
$\mathrm{P}_{\text {GenReq. }}$ & $52.723 \times 2 \mathrm{~kW}$ & $50.841 \times 2 \mathrm{~kW}$ \\
$\mathrm{P}_{\text {Generator }}$ & $60 \times 2 \mathrm{~kW}$ & $60 \times 2 \mathrm{~kW}$ \\
\hline \hline
\end{tabular}

Selain itu perbedaan sarat kapal juga berdampak pada perbedaan freeboard, seperti:

Tabel 6.

Rekapitulasi Berat - Titik Berat dan Freeboard

\begin{tabular}{crr}
\hline \hline Komponen & Perairan Sungai & \multicolumn{1}{c}{ Perairan Laut } \\
\hline DWT & 1444.167 ton & 1444.093 ton \\
LWT & 664.802 ton & 682.823 ton \\
LWT+DWT & 2108.968 ton & 2126.916 ton \\
LCB & $25.528 \mathrm{~m}(\mathrm{FP})$ & $25.528 \mathrm{~m}(\mathrm{FP})$ \\
LCG & $25.358 \mathrm{~m}(\mathrm{FP})$ & $25.333 \mathrm{~m}(\mathrm{FP})$ \\
Freeboard & $1571.869 \mathrm{~mm}$ & $1647.257 \mathrm{~mm}$ \\
\hline
\end{tabular}

Di bawah ini merupakan analisis terhadap hasil dan kriteria stabilitas yang disyaratkan dalam IS (Intact Stability) Code:

Tabel 7.

Rekapitulasi Stabilitas

\begin{tabular}{ccccc}
\hline \hline Kriteria & $\begin{array}{c}\text { Batasan (IS } \\
\text { Code) }\end{array}$ & $\begin{array}{c}\text { Harga } \\
\text { Stabilitas }\end{array}$ & Satuan & Status \\
\hline e $0-30^{\circ}$ & 0.055 & 0.70 & m.rad & Pass \\
e $0-40^{\circ}$ & 0.09 & 0.98 & m.rad & Pass \\
e $30-40^{\circ}$ & 0.03 & 0.28 & m.rad & Pass \\
GZ $30^{\circ}$ & 0.2 & 0.59 & $\mathrm{~m}$ & Pass \\
GM $0^{\circ}$ & 0.15 & 1.97 & $\mathrm{~m}$ & Pass \\
$\phi^{\circ}$ max & 25 & 26.25 & $\circ$ & Pass \\
\hline \hline
\end{tabular}

\section{Analisis Ekonomis Terhadap Hasil Optimisasi}

Besar biaya pembangunan dapat ditentukan dengan persentase biaya pembangunan berdasarkan modul Estimasi Harga Pembangunan Kapal Baru [2] [5].

Besar biaya komponen baja didapatkan dari berat baja kapal yang dikalikan dengan harga baja per satuan ton. Keadaan yang dijadikan acuan perhitungan estimasi biaya pembangunan adalah Self-Propelled Car Barge dengan 
kondisi pelayaran di perairan laut, dikarenakan memiliki kebutuhan berat yang lebih besar dibandingkan kondisi pelayaran sungai.

$$
\begin{aligned}
\text { \$Steel Plate } & =\mathrm{W}_{\mathrm{S}} \times \mathrm{UP}_{\mathrm{S}} \\
\mathrm{W}_{\mathrm{S}}= & 579.63 \text { ton } \\
\mathrm{UP}_{\mathrm{S}}= & \text { Unit Price } \text { Baja } \\
= & \$ 520.0 / \text { ton }[3][8] \\
\text { Steel Plate }= & \$ 301406.818 \\
\% \text { Total Cost }= & 21 \%
\end{aligned}
$$

Biaya pembangunan dari komponen lainnya dihitung berdasarkan harga baja yang dijadikan acuan dan persentase dari masing-masing komponen. Contoh perhitungan biaya dari persentase yang ada didapatkan sebagai berikut:

$\$$ Komponen $=(\%$ Komponen $/ \%$ Acuan $) \times \$$ Acuan

Sebagai contoh mencari biaya dari design cost (\$ Desain)

$$
\begin{aligned}
\% \text { Desain } & =3.00 \%(\text { Total Cost }) \\
\% \text { Acuan } & \% \text { Steel and profile } \\
& =21.00 \%(\text { Total Cost }) \\
\text { Acuan } & =\$ \text { Steel and profile } \\
& =\$ 301406.818 \\
\% \text { Desain } & =(3.00 / 21.00) \times 301406.82 \\
& =\$ 43058.12
\end{aligned}
$$

Dari contoh perhitungan di atas, maka didapatkan besar biaya pembangunan dengan rincian seperti pada tabel 8. Dari rincian estimasi biaya pembangunan pada tabel 8 , diketahui bahwa estimasi biaya pembangunan total sebesar 1.435.270,56 USD. Kurs jual USD terhadap Rupiah menurut indeks mata uang Bank Indonesia per tanggal 14 Juni 2016 sebesar Rp. 13.339,00. Maka estimasi biaya pembangunan total dalam Rupiah sebesar Rp. 19.145.073.999,00.
Tabel 8 .

Estimasi biaya pembangunan TSHD



E. Pembuatan Rencana Garis dan Rencana Umum

1) Rencana Garis (Lines Plan)

Proses pembuatan rencana garis Self-Propelled Car Barge dengan memperhatikan dan menyesuaikan kriteria teknis, seperti ukuran utama dan koefisien yang ada. Berikut hasil desain Rencana Garis Self-Propelled Car Barge dengan software Autocad: 


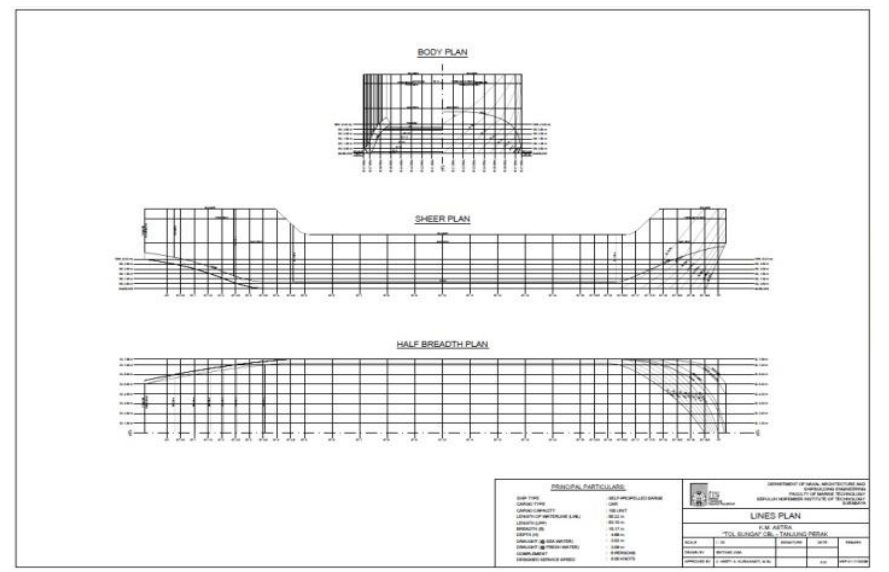

2) Rencana Umum (General Arrangement)

IProses pembuatan desain rencana umum dari SelfPropelled Car Barge dilakukan dengan menggunakan bantuan software Autocad dengan memperhatikan perencanaan dan pembagian ruang untuk semua kebutuhan dan perlengkapan kapal sesuai lokasi dan akses yang dibutuhkan sesuai dengan peraturan dan regulasi yang ada. Berikut hasil desain Rencana Umum SelfPropelled Car Barge (Gambar 8):

Gambar. 7. Rencana Garis

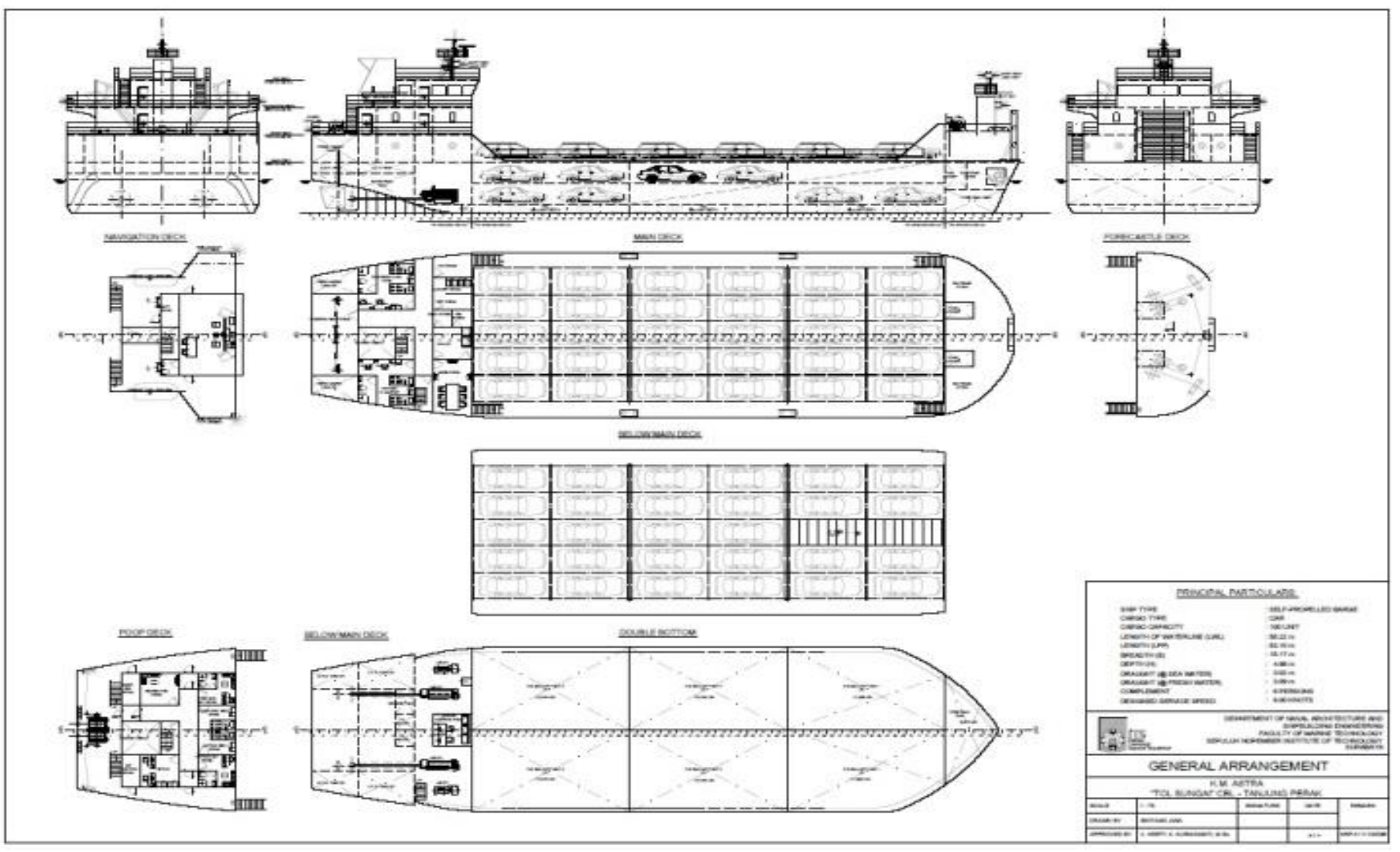

Gambar. 7. Rencana Umum

\section{KESIMPULAN DAN SARAN}

Dari analisis yang telah dilakukan baik teknis maupun ekonomis, maka dari Jurnal ini dapat ditarik kesimpulan sebagai berikut:

1) Ukuran utama optimum untuk Self-Propelled Car Barge yang telah memenuhi kriteria persyaratan teknis dari hasil optimisasi adalah sebagai berikut:

Untuk kondisi pelayaran di perairan sungai didapatkan:
a. L $\quad: 53.097 \mathrm{~m}$
b. B : $15.170 \mathrm{~m}$
c. $\mathrm{T}_{\mathrm{FW}}: 3.091 \mathrm{~m}$
d. $\mathrm{H} \quad$ : $4.663 \mathrm{~m}$

2) Sedangkan untuk kodisi pelayaran di perairan laut didapatkan:
a. L : $53.097 \mathrm{~m}$
b. B : $15.170 \mathrm{~m}$
c. $\mathrm{T}_{\mathrm{SW}}: 3.016 \mathrm{~m}$
d. $\mathrm{H} \quad$ : $4.663 \mathrm{~m}$

3) Total estimasi biaya pembangunan Self-Propelled Car Barge berkapasitas 60 TEUs untuk program Tol Sungai Cikarang Bekasi Laut - Tanjung Priok ini didapatkan sebesar \$1.435.270,56 atau setara dengan Rp.19.281.424,757, -

Saran kedepannya yang dapat diberikan dari Jurnal ini antara lain:

1) Mengingat Self-Propelled Car Barge ini didesain untuk melalui dua kondisi perairan yang berbeda yaitu perairan 
sungai dan laut, maka diharapkan adanya pembahasan yang lebih mendetail terhadap kemampuan olah gerak kapal.

2) Perlu adanya peninjauan lebih rinci terhadap aspek konstruksi dan kekuatan kapal mengingat program Tol Sungai ini memliki kemungkinan untuk direalisasikan, sementara pada Jurnal ini masih banyak digunakan perhitungan secara pendekatan.

3) Serta diharapkan adanya perhitungan dan analisis yang riil terhadap biaya pembangunan yang dibutuhkan untuk membangun Self-Propelled Car Barge guna mendukung terealisasinya program Tol Sungai ini.

\section{DAFTAR PUSTAKA}

[1] T. Tabaczek, "Analysis of Hull Resistance of Pushed Barges in Shallow Water," Polish Maritim Research, 2007.

[2] The Steel Index, "Steel Index Reference Prices (June 08-14)," thesteelindex.com, 2015.
[3] Anonim, "News: Pengusaha Tak Sabar Angkutan Kontainer via Sungai Segera Beroperasi di Bekasi," detik.com, 6 Februari 2015. [Online]. Available:

http://finance.detik.com/read/2015/02/06/100534/2825373/4/pengusahatak-sabar-angkutan-kontainer-via-sungai-segera-beroperasi-di-bekasi. [Accessed 6 Februari 2015].

[4] PERTAMINA, Estimasi Harga Pembangunan Kapal Baru, Jakarta: PERTAMINA, 2007.

[5] Rijkswaterstaat, Waterway Guidlines, Netherland: Ministrie van Infrastructuur en Milieu, 2011.

[6] P. U. R. I. K., "Laporan Perecanaan dan Detail Desain Pengendalian Banjir Sungai CBL," Satuan Kerja Balai Wilayah Sungai Ciliwung Cisadane, Jakarta, 2008.

[7] W. D., "Practical Ship Design," Elsevier, 1998.

[8] Anonim, "News: Rini Laporkan Progress Proyek Waterway ke Jokowi," TEMPO, 5 February 2015. [Online]. Available: http://www.tempo.co/read/news/2015/02/05/090640134/Rini-LaporkanProgres-Proyek-Waterway-ke-Jokowi.. [Accessed 6 February 2015]. 